\title{
Storage Period of Liquid Semen Eligible for Insemination in Thin Tail Sheep Semen Diluted with Egg Yolk Citrate with the Addition of Noni (Morinda citrifolia Linn) Fruit Extract
}

\author{
Sigit Bintara ${ }^{1 *}$, Ismaya Ismaya ${ }^{1}$, Diah Tri Widayati ${ }^{1}$, Riyan Nugroho Aji ${ }^{1}$, and \\ Widya Asmarawati ${ }^{1}$
}

${ }^{1}$ Faculty of Animal Science Universitas Gadjah Mada
${ }^{*}$ Corresponding author. Email: sigitbintara@ugm.ac.id

\begin{abstract}
Semen processing can reduce the motility and viability of the sperm. The focus of this research was to evaluate the shelflife of liquid semen which could still be used for insemination in thin tail sheep semen diluted with Egg Yolk Citrate and noni (Morinda citrifolia Linn) extract. Semen was collected from 2 years-old thin tail sheep using an artificial vagina. The sperm was analyzed at the UGM Faculty of Animal Science's Laboratory of Animal Physiology and Reproduction. In this research, the treatments were egg yolk citrate diluent (P0) as a control, $\mathrm{P} 0+4 \%$ noni extract $(\mathrm{P} 1), \mathrm{P} 0+6 \%$ noni extract $(\mathrm{P} 2)$, and $\mathrm{P} 0+8 \%$ noni extract $(\mathrm{P} 3)$. The variables measured were the macroscopic quality of the semen as well as microscopic quality of spermatozoa. The results showed that the addition of noni extract could improve $(\mathrm{P}<0.05)$ motility and viability of spermatozoa stored at $5^{\circ} \mathrm{C}$. The addition of $4 \%$ noni fruit extract generated the best results in terms of preserving motility $(44.2 \%)$ and spermatozoa viability $(68.4 \%)$ after 5 days of storage. The conclusion of this study, day five storage of thin tail sheep liquid semen diluted with egg yolk citrate and $4 \%$ noni fruit extract at $5^{\circ} \mathrm{C}$ was still eligible for insemination.
\end{abstract}

Keywords: Maximum storage period; Liquid semen; Insemination eligible; Thin tail sheep; Noni fruit extract

\section{INTRODUCTION}

Thin tail sheep were a popular sheep breed originating from Indonesia, the most effective and efficient way to improve the quality and quantity from this sheep was used Artificial Insemination (AI) methods. For several decades, the AI method has been growing rapidly in Indonesia. The advantage of AI was that it could increase the number of offspring conceived by superior rams. Frozen sperm contributes to the effectiveness of AI programs. Assessment of spermatozoa concentration, morphological characteristics, motility, and viability throughout the processing, as well as successive fertilization capabilities [1]. However, during the freezing process, the process produces free radicals like lipid peroxidation and reactive oxygen species (ROS) that leads the sperm damage and reduces the viability or motility of spermatozoa by redox deregulation[2]. Vitamin $\mathrm{C}$ or ascorbate acids has been considered in preset studies as an antioxidant to prolong life span of ram semen which undergo the chilling process. The ascorbate acid was able to snare ROS before that's radicals could embark oxidative chain reaction and maintain the sperm quality after chilling process [2], [3].

Noni fruits (Morinda citrifolia Linn) contains many antioxidant including the ascorbate acids, carotenem xeronine and proxeronine which has been known could effectively protect against free radicals [4]. Ascorbic acid has the capacity to maintain the quality of ram sperm by enhancing membrane plasma stability and preserving against lipid peroxidation [5]. 
Based on these findings, this study examined the benefits of the addition of Noni (Morinda citrifolia Linn) extract in egg yolk citric diluents as an option diluent that could significantly raise motility and viability in thin tail rams' sperm.

\section{MATERIAL AND METHOD}

\subsection{Animals and chemicals}

Two mature local ram reproductive tracts were kept under standard field and laboratory environments and carried out in compliance with university guidelines. Diluent liquid andromed (Minitube, Germany), exogenous glutathione (GSH) (Merck, Germany), eosin (Sigma-Aldrich, USA), liquid nitrogen, and aqua bi-dest were the chemicals used.

\subsection{Semen collection and initial evaluation}

The sperm quality had first been evaluated after the sperm was collected using an artificial vagina. Semen does have normal color, $0.8 \pm 0.2 \mathrm{~mL}$ volume, $>80 \%$ motility and viability, and $3600 \pm 120.2110^{6} \%$ $\mathrm{mL}$ concentration, with $10 \%$ abnormality. Noni fruit extract was made by macerating dried noni fruits in 96 percent ethanol for 24 hours and stirring three times per day for three days.

\subsection{Post Chilled Semen evaluation}

To mitigate individual effects, the sperm ejaculates were pooled. Initially, the pooled sperm was diluted 1:4 with egg yolk citrate. The diluted samples were split into 4 aliquots depending on the concentration of Noni fruit extract (P0 0\% control; P1:4\%; P2: 6\%; and P3:8\%). The samples were kept in a cold cabinet at 5 degrees Celsius for 6 days and were assessed for sperm motility and membrane integrity on days 5 and 6 . The sperm motility was observed by simply putting $10 \mathrm{~L}$ of diluent mixed with $\mathrm{NaCl}(1: 4)$ on the microscope and homogenizing it (Olympus $\mathrm{CH} 20$ ). The approach was taken from ten fields at a magnification of $100 \times 400$, and the scores ranged from $0 \%$ to $100 \%$ on a 5-point scale [6]. For sperm viability, an eosin staining protocol was used. To distinguish between reacted and non-reacted spermatozoa, 200 spermatozoa were counted per sample using a light microscope (Olympus CH 20). Death sperm with a damaged acrosome emitted a strong red color, whereas non-reacted sperm emitted a light pink or no-color.

\subsection{Statistical analyzed}

The results were presented as the mean standard deviation (SD). The statistically significant difference between the mean values was determined using oneway ANOVA followed by the Duncan post hoc test with $\mathrm{p}<0.05$ as the statistically significant criterion. Four independent experiments were performed out.

\section{RESULT AND DISCUSSION}

The data revealed that the rate of motility in D-5 for P1, P2, and P3 were 30.3\%, 44.2\%, 40.7\% respectively and $39.6 \%$ whereas for D-6 were $25.2 \%$, $35.3 \%, 31.6 \%$ and $30.3 \%$ respectively. The viability rate in $\mathrm{D}-5$ for $\mathrm{P} 1, \mathrm{P} 2$, and $\mathrm{P} 3$ were $55.4 \%, 68.4 \%$, $64.3 \%$ dan $64.4 \%$ respectively, whereas in D-6 were $40,3 \%, 47,2 \%, 45,4 \%$ dan $45,2 \%$ respectively. Based on the data (Table 1), the percentages of motility and viability spermatozoa were significantly decreased $(\mathrm{p}$ $<0.05$ ) during storage time, this result similar with previous study [7] that stated the percentage of sperm would decrease along with the shelf life due to the reduced of metabolite energy from spermatozoa and leads to increase $\mathrm{pH}$ ambient which also directly triggering sperm damage by increased of cellular damage [5]. Cryopreservation, which includes storage time and thawing alter sperm membrane and produces oxidative agent [8], and get worse because seminal plasma removal procedures during the preservation process [7]. Due to the reduced concentration of cytoplasm in sperm, seminal plasma acts as a buffer against ROS in vivo [9]. As a direct consequence, cryopreservation decreases the concentration of antioxidant compounds and diminishes sperm protection [10].

The highest percentage of sperm motility and viability was discovered in D-5 and D-6, which was

Table 1. The effect of Noni extract (Morinda citrifolia Linn) in semen extender on Thin Tail Ram sperm motility and viability stored at $5^{\circ} \mathrm{C}$ for D-5 until D-6

\begin{tabular}{|c|c|c|c|c|c|c|}
\hline \multirow{2}{*}{ Noni extract } & \multicolumn{3}{|c|}{ Motility (\%) } & \multicolumn{3}{c|}{ Viability (\%) } \\
\cline { 2 - 7 } & D-1 & D-5 & D-6 & D-1 & D-5 & D-6 \\
\hline Control & $84.0 \pm 2.3^{\mathrm{a}}$ & $30.3 \pm 1.6^{\mathrm{Ab}}$ & $25.2 \pm 1.8$ & $87.0 \pm 1.6^{\mathrm{a}}$ & $55.4 \pm 1.5$ & $40.3 \pm 1.9^{\mathrm{Ab}}$ \\
\hline $4 \%$ & $86.2 \pm 2.0^{\mathrm{a}}$ & $44.2 \pm 1.8^{\mathrm{Bb}}$ & $35.3 \pm 2.2$ & $89.0 \pm 0.7^{\mathrm{a}}$ & $68.4 \pm 1.1$. & $47.2 \pm 1.3^{\mathrm{Bb}}$ \\
\hline $6 \%$ & $87.0 \pm 1.7^{\mathrm{a}}$ & $40.7 \pm 2.6^{\mathrm{Bb}}$ & $31.6 \pm 1.1$ & $90.0 \pm 2.2^{\mathrm{a}}$ & $64.3 \pm 1.6$ & $45.4 \pm 2.4^{\mathrm{Bb}}$ \\
\hline $8 \%$ & $85.0 \pm 1.7^{\mathrm{a}}$ & $39.6 \pm 1.5^{\mathrm{Bb}}$ & $30.3 \pm 2.8$ & $88.2 \pm 1.3^{\mathrm{a}}$ & $64.4 \pm 1.3$ & $45.2 \pm 1.9^{\mathrm{Bb}}$ \\
\hline
\end{tabular}

Means in a row not sharing superscript show significant differences ( $\mathrm{p}<0.05)$ for $\mathrm{GSH}$ addition $(\mathrm{ab}, \mathrm{AB})$; data were expressed as means \pm SEM 
P1 (4\%) in D-5. This demonstrated that the addition of Noni fruit extract in egg yolk citrate diluent might significantly preserve the standards of thin tail ram sperm during storage at $5^{\circ} \mathrm{C}$ for 6 days, even though the best results were obtained at D-5. The result also showed that the infused of noni extract in P1 (4\%) and $\mathrm{P} 2(6 \%)$ to the sperm diluent could maintain the sperm post thawing motility (PTM) in $40 \%$ which still suitable for insemination [11]. The high percentage of sperm motility in P1 and P2 due to the high vitamin C content of noni fruit [12] which was $29.29 \mathrm{mg} / \mathrm{ml}$ [13]. Ascorbic acids could preserve spermatozoa against ROS accumulation during cryopreservation by diminished ROS induced in sperm DNA also reduced lipid peroxidation[14]. Ascorbic acid scavenge and quench free radicals [9]. Increased motility rates and viability rates in treatment semen compared with the control also due to in treatment semen these ascorbic acid diminished lipid peroxidation [7]. Ascorbic acids as antioxidant were against the ROS by made a linked with oxidative agent and induced the ATP availability and increased the motility[15]. Previous study found that addition Noni extract (Morinda citrifolia Linn) $(0.02 \mathrm{~g} / \mathrm{ml}$ egg yolk citrate diluent) could maintain the liquid semen quality which were motility and viability in $5^{\circ} \mathrm{C}$ storage temperature for 5 days in buffalo and Bali cattle [16]. Antioxidant addition such as ascorbate acids could prevent spermatozoa by minimizing the negative effects of free radicals on spermatozoa cells, damage to cell morphology that might cause abnormalities in spermatozoa cells can be avoided [17]. The metabolic process would function efficiently with an intact plasma membrane, ensuring that energy production in the form of ATP is not disrupted, allowing spermatozoa to keep their motility and viability [18].

\section{CONCLUSION}

The addition of $4 \%$ noni fruit extract gave the best results in terms of maintenance motility (44.2\%) and spermatozoa viability (68.4\%) for 5 days of storage. The conclusion of this study, day five storage of thin tail sheep liquid semen diluted with egg yolk citrate and $4 \%$ noni fruit extract at $5^{\circ} \mathrm{C}$ was still eligible for insemination.

\section{REFERENCES}

[1] Doležalová,M., L. Stádník, Z. Biniová, J. Ducháček, and J. Beran. 2015. The effect of the freezing curve type on bull spermatozoa motility after thawing. Acta Vet. 54:383-391.

[2] Riesco, M. F., M. Alvares, L. A. Lopez, M. N. Montero, C. P. Martinez, R. M. Garrido, J. C. Boixo, P. de Paz, L. Anel. 2021.Multiparametric study of antioxidant effect on ram sperm cryopreservation - from field trials to research bench. Animals. 11(2):1-14.

[3] Esguerra, J. P. M., J. M. U. P. H. Quimio, G. A. Dichoso, C. A. L. Junsay, V. A. Magpantay, and P. P. Sange. 2020. Coconut water with either tomato juice or garlic extract as extender components for Paraoakan native chicken semen at different storage temperatures. Philipp. J. Sci., 149 (1):121-131.

[4] Yahaq, M. A., Y. S. Ondho., Sutiyono. 2019. Pengaruh penambahan vitamin $\mathrm{c}$ dalam pengencer semen sapi limosin yang dibekukan terhadap kualitas post thawing. Jurnal Sain Peternakan Indonesia. 14(4):380-386.

[5] Thasmi, C. N., M. Ikhsanuddin, H. Hamdan, D. Dasrul, M. N. Salim, and A. Azhar. 2020. Effect of Noni Fruit Extract (Morinda citri-folia L.) in CitrateYolk Diluent on The Boer Goat Spermatozoa Motility Stored at Temperature $5^{\circ} \mathrm{C}$," E3S Web Conf., 151:1-5.

[6] Priyanto, L., R. I. Arifiantini, T. L. Yusuf. 2015. Deteksi Kerusakan DNA Spermatozoa Semen Segar dan Semen Beku Sapi Menggunakan Pewarnaan Toluidine Blue. J. Vet. 16(1):48-55.

[7] Breininger E., and M. T. Beconi. 2014. Ascorbic acid or pyruvate counteracts peroxidative damage in boar sperm cryopreserved with or without $\alpha$-tocopherol. Anim. Sci. Pap. Reports, 32(1):15-23.

[8] Len, J. S., W. S. D. Koh, and S. X. Tan. 2019. The roles of reactive oxygen species and antioxidants in cryopreservation. Biosci. Rep. 39(8): 1-25.

[9] Bansal, A. K., and G. S. Bilaspuri. 2011. Impacts of oxidative stress and antioxidants on semen functions. Vet. Med. Int. 2011: 686137.

[10] Buranaamnuay, K., P. Tummaruk, J. Singlor, H. Rodriguez-Martinez, and M. Techakumphu. 2009. Effects of straw volume and equex-STM® on boar sperm quality after cryopreservation. Reprod. Domest. Anim. 44(1):69-73.

[11] Herbowo, M. T., R. I. Arifiantini, N. W. K. Karja, and R. G. Sianturi. 2019. Cryopreservation of swamp buffalo semen in skim milk yolk-based diluent with two different cryoprotectants," Trop. Anim. Sci. J., 42(1):1318.

[12] Trilaksana, I., R. Ndun, and W. Bebas, 2015. Penambahan Vitamin C Pada Pengencer Fosfat Kuning Telur Semen Kalkun Yang Disimpan Pada Suhu $5^{\circ} \mathrm{C}$ Bul. Vet. Udayana,7(2):186-193. 
[13] Murcahyana, M.,T. Susilawati, and N. Isnaini. 2016. Effect of Noni Extract Fruit (Morinda citrifolia) in Physiological Saline Solution as Diluent on the Native Chicken Spermatozoa Quality at Room Temperature). J. Kedokt. Hewan - Indones. J. Vet. Sci., 10(2):175-180.

[14] Fannaei, H., S. Khayat, I Halvet, V. Ramezani, A. Kasaenian, J. Mardanch, M. R., Parvis, M. Akharmi. 2014. Effects of ascorbic acid on sperm motility, viability, acrosome reaction and DNA integrity in teratozoospermic samples. Iran. J. Reprod. Med.,12(no)2:103-110.

[15] Tanner, A. R., C. V. C. Kennedy, M. L. Bauer, K. C. Kendall, J. D. Kirsch, J. Gaspers, N. N. Pereira, A. B. P. Founroura, G. A. Perry, G. Stokka, A. R. Gonzalez, A. Ward, C. R. Dahlen, B. Neville, L. P. Reynolds, K. H. Ominski, K. A. Vonna. 2018. Corn supplementation as a winterfeeding strategy alters maternal feeding behavior and endocrine profiles in mid-to late-gestating beef cows. Transl. Anim. Sci., 2:S106-S111.

[16] Rophi, A. H., S. Rahayu, and G. Ciptadi, 2018. The Effect of Morinda citrifolia L. Fruit Extract Supplemented in to Diluent Tris-Egg Yolk Toward the Abnormality of Goat's Spermatozoa after Freezing at $-80^{\circ} \mathrm{C}$. J. Exp. Life Sci., 8(3):145-152.

[17] Banday, M. N., F. A. Lone, F. Rasool, M. Rashid, and A. Shikari. 2017. Use of antioxidants reduce lipid peroxidation and improve quality of crossbred ram sperm during its cryopreservation. Cryobiology. 74:25-30.

[18] de Jong, A. M. E., R. Menkveld, J. W. Lens, S. E. Nienhuis, and J. P. T. Rhemrev. 2014. Effect of alcohol intake and cigarette smoking on sperm parameters and pregnancy. Andrologia. 46(2):112-117. 